\title{
Moderating Effect of the Situation of Return or Relocation on the Well-Being and Psychosocial Trauma of Young Victims of the Armed Conflict in Colombia
}

\begin{abstract}
Sandra Milena Quintero-González*, Camilo Alberto Madariaga-Orozco, Anthony Constant Millán-de Lange, Diany Marcela Castellar-Jiménez and Jorge Enrique Palacio-Sañudo
\end{abstract}

Departamento de Psicología, Universidad del Norte, Barranquilla, Colombia

Colombia is the second country with the highest number of internally displaced persons. In the last 10 years, more than 400,000 young people carry, in their life experiences, the title of victims. The psychological and social circumstances that determine the lives of displaced young people in the world are not unknown. Fear, the poor resources for social adaptation available to them, and the possible reproduction of the cycle of violence, represent psychosocial risk factors in the young and displaced population. In this context, the Victims Law in Colombia stipulated various measures of repairment, including Relocation (the person or household victim of forced displacement decides to settle in some place, other than the one they were forced to leave) and Return (the person or the household victim of forced displacement decides to return to the place from which they were displaced, in order to settle indefinitely) provided the conditions of voluntariness, security, and dignity are present. A hypothesis that well-being will be better in the returnees was set, since they would strengthen the social support networks between neighbors and other victims in their old spaces of life. To test the hypothesis, the scales of Psychological Well-being, Social Well-being, the Satisfaction with Life Scale, and the Psychosocial Trauma Scale were applied to young returnees $(n=129)$ and relocated $(n=259)$ in Colombia. The Exploratory and Confirmatory Factor Analysis was performed to extract the general measure of well-being and psychosocial trauma followed by the comparison between the groups. Significance, power, and effect size indicators were obtained, and finally, the partial correlation between the groups was made in relation to psychosocial trauma and well-being. Results showed that returnees have greater well-being and clearer indicators $(d=0.365,1-\beta=0.996)$, with respect to that of relocated. In addition, the well-being of returnees has fewer trauma factors, who in turn are quasi-moderated by the situation of return or relocation.

Keywords: well-being, psychosocial trauma, youth, victims, repair, moderating effect, armed conflict

Abbreviations: ACNUR, United Nations High Commissioner for Refugees; UARIV, Unit for Comprehensive Attention and Reparation for Victims; KMO, Kaiser-Meyer-Olkin Measure; GFI, goodness of fit index; RMSEA, root mean square error approximation; ECVI, expected cross validation index; AGFI, adjusted goodness of fit index; PNFI, parsimony normed fit index; PGFI, parsimony goodness of fit index; K-S $S_{L}$, Lilliefors; DW, Durbin-Watson coefficient index; K-S, KolmogorovSmirnov test. 


\section{INTRODUCTION}

For 4 years in a row, Colombia has ranked second on the list of countries with the highest number of displaced people in the world (Alto Comisionado de las Naciones Unidas para los Refugiados [ACNUR], 2019). To date, there are more than 8 million forcibly displaced persons, including 3 million youth, of which 17,728 have returned and/or relocated between 2010 and 2018 (Unidad de Atención y Reparación Integral a las Víctimas [UARIV], 2020). History marks them: the more than 60 years of violence caused by a sociopolitical conflict that has not ceased. Collective violence is a phenomenon of great instrumental and emotional impact (Arendt, 2005; Blanco et al., 2016). The depth of the sequelae generated by this phenomenon has strong repercussions at an individual level, in terms of the destruction of a life project, and at a collective level, in the destruction or reformulation of social and support networks (Thompson and Walsh, 2010).

The Law in Colombia has established the restitution of rights to restore, to the greatest degree possible, the state of life in which people were prior to their forced displacement, (Ley de 387, 1997, chapter II; Ley de 1448, 2011, chapter II; Unidad de Atención y Reparación Integral a las Víctimas [UARIV], 2020). They have two options under the principles of security, voluntariness, and dignity: One is to return, if their decision is aimed at reintegrating to the place where they were forced to leave through the use of violence; and another is to relocate, if they choose to rebuild their life in a place other than the place of origin (Ley de 387, 1997, Chapter II). Which of the two conditions could be more favorable for the displaced, in light of its impact on well-being and the psychosocial trauma they have experienced?

The concept of return began to be studied at the end of the Second World War (Black and Gent, 2006). South Sudan, Bosnia and Herzegovina, Uganda, and Afghanistan appear as the countries with the highest returns, within and toward them, with loss of confidence and doubts about their own capacities, destruction of homes, despair, a pessimistic view of the world, among others, influencing the decision to return or to relocate (Bozzoli et al., 2012; Haroz et al., 2013; Huser et al., 2019; Sullivan, 2019; Renner et al., 2020), and affect their well-being (Siriwardhana and Stewart, 2013). Various international studies have focused on this population in order to better understand the consequences of return and relocation on the well-being of these victims (Diener and Diener, 1995; Black and Gent, 2006; Siriwardhana and Stewart, 2013; Burns et al., 2018).

Despite the fact that, in Colombia, research has been developed in relation to forced displacement, the scientific study of return and relocation is recent, and perhaps this leads to limited scientific and empirical evidence from the country (Ibáñez and Querubín, 2004; Hernández, 2010; Garzón, 2011; Siriwardhana and Stewart, 2013), especially the experience of trauma and well-being in the younger population. Some qualitative studies or bibliographic reviews highlight that situations of violence, previously unfounded terrors, and threats of being displaced again, become elements that hinder return processes (Lima and Reed, 2000; Chávez and Falla, 2005; Correa De Andreis, 2009; Garzón, 2011). Returning to the place of origin does not only imply a return, but a reconstruction and resignificance of the territory, a desire to re-have the experiences they lived there, linking affective components, including identity, in the territory where they would have already configured their life project (Posada et al., 2013; Velásquez and Céspedes, 2019).

The communities formed in new spaces are not natural or spontaneous, but created by administrative acts of the State, to comply with the law, rather than in the sense of comprehensive reparation to the victims (Arango and Arroyave, 2017). The traumatic experience can transform the structure of values and beliefs in different areas (personal, family, social) (MedinaMontañez et al., 2007; Blanco et al., 2016), and it differs according to groups and social classes (Madariaga, 2002).

The concept of psychosocial trauma has historically been approached from different perspectives, disciplines, and contexts (Freud, 1948; Chía-Chávez et al., 2011; American Psychiatric Association [APA], 2013; Bohigas et al., 2015). In the 20th century, the psychosocial period of trauma began, under the gaze of historical trauma (Bohigas et al., 2015). In the 90s, Ignacio Martín-Baró placed it in the Latin American context as "Psychosocial Trauma," and defined it as "the crystallizationor materialization-in individuals of aberrant and dehumanizing social relationship such as those that prevail in situations of civil war" (Martín Baró et al., 1990, p. 236). Martín-Baró also identifies resources and positive elements in this experience of violence, which result from the need to continue life, since "the injury or affectation will depend on the peculiar experience of each individual, an experience conditioned by their social extraction, by their degree of participation in the conflict, as well as other characteristics of his personality and experience" (Martín Baró, 1990, p. 10). As main characteristics or factors that make up this concept of psychosocial trauma, the following are proposed: (1) the pre-traumatic situation referred to the causes of the generated trauma; (2) the personal, family, and community destruction as a consequence of the traumatic event; (3) disintegration of the inner world, the disintegration of beliefs about oneself, about others, and society; (4) intergroup emotions as emotional reactions referring to oneself, their community, and to the "others" (victimizers); (5) expression of emotional ambivalence such as the coexistence of positive and negative emotions toward the trauma; (6) recognition of personal capacities to overcome trauma; and finally (7) personal and collective efficacy (Blanco et al., 2014; Quintero, 2020 in press).

The experience of violence in Colombia carries the cross of trauma in a totally dehumanized and cold context. Enough research has studied the painful effect of collective violence on the displaced, demonstrating the destruction of territories of life, communal identities (Correa De Andreis, 2009; Cardozo Rusinque et al., 2017); post-traumatic stress disorders (PTSD), mood disorders (Aristizábal et al., 2012), detrimental quality of life, social media breakdown, modification of family roles, and family disintegration (Bell et al., 2012; Charry-Lozano, 2016; Sánchez et al., 2019).

Different authors affirm that the condition of returning or relocating can be, in itself, a traumatic event, especially after a prolonged displacement. The social and cultural ties established with the new place of settlement can be broken, feelings of 
helplessness and distrust appear, and the new generations that were born after displacement may have difficulties in adapting to an unknown place (Siriwardhana and Stewart, 2013; Arévalo, 2016; Sánchez et al., 2019). Either of these two ways requires the reconstruction of their well-being, so understanding trauma during this reintegration is complex (De Smet et al., 2019; Huser et al., 2019).

Positive Psychology at the end of the 90s has been in charge of precisely this: recognizing the positive and well-being aspects that are a fundamental part of human life, despite the painful experiences that life offers (Seligman and Csikzentmihalyi, 2001). As it is known, the first conceptualizations about well-being had their origin in the philosophical reflections of two traditions: the Eudaimonic Tradition, associated with individual and social human development (Ryff, 1989; Keyes, 1998); and the Hedonic Tradition, related to the effects and cognitions of an individual with respect to their own life (Diener, 1984; Keyes et al., 2002).

Indeed, well-being is closely linked to psychological and social experience (Seligman and Csikzentmihalyi, 2001; Keyes, 2005). The complete state of health model proposed by Keyes (2005), measured with the variables of psychological and social wellbeing and life satisfaction, has been widely used in research with victims of displacement in Colombia (Palacio et al., 1999; Palacio and Sabatier, 2002; Manrique et al., 2008; Abello-Llanos et al., 2009; Campo-Arias and Herazo, 2014; Amaris et al., 2019). However, a large number of researchers have concluded that it is possible to measure the well-being construct from a general score that underlies the scores of these variables as a whole (Keyes, 2005; Díaz et al., 2007; Kokko et al., 2013; Hides et al., 2016; Peña Contreras et al., 2017).

Along these lines, and given the existence of multiple instruments that measure well-being (Diener et al., 1985; Ryff, 1989; Ryff and Keyes, 1995; Keyes, 2005; Sisask et al., 2008; McDowell, 2010; Schneider et al., 2010; Kokko et al., 2013, p. 110; Hides et al., 2016; Peña Contreras et al., 2017) it became necessary to have a methodology that would allow a unified measure of well-being from different sources of record. Therefore, in this study, a factorial analysis that allowed finding a common structure between them was carried out. Based on these results, it was determined that the construct of "general well-being" describes the positive functioning of the well-being of a person in their psychological, social, and subjective domains (Keyes, 2005; Castellar, 2020, in press).

Not knowing and not addressing the experience of pain and suffering of young returnees and relocated, prevents the recognition of the impact and effectiveness of their condition of reparation (whether as returned or as relocated) for the reconstruction of their life project and well-being (Rebolledo and Rondón, 2010). This is why the relationship between psychosocial trauma and well-being is possibly moderated by the situation of return or relocation of the young victims. Starting from the difference between moderation and mediation in psychological studies (Baron and Kenny, 1986; Wen et al., 2005; Hayes, 2018) the experience of return or relocation can determine the effect of interaction in the relationship between psychosocial trauma and wellness. Identifying the moderating effect of this variable will allow researchers/professionals to plan their interventions to maximize the levels of well-being of the population (Internal Displacement Monitoring Centre [IDMC], 2020). To test its effect, a hypothesis is proposed: well-being and trauma are different according to the type of situation (return or relocation) of the young person.

\section{MATERIALS AND METHODS}

\section{Design}

A retrospective ex-post-facto design was used, with the dependent variable (general well-being) being initially studied, and then independent variables (psychosocial trauma factors) being tested (Montero and León, 2007).

\section{Sample}

The universe was made up of young victims of forced displacement, returned or relocated in the departments of Atlántico, Sucre, and Cesar (northern Colombia). The following was used as inclusion criteria: (1) that the participants were registered in the Single Registry of Victims (RUV). (2) That they were linked to return or relocation programs. (3) That they expressed willingness to participate. As an exclusion criterion, the category "Youth" in Colombia describes those persons whose ages range between 14 and 26 years of age, as established in Ley de 387 (1997). However, although they are young, all minors were excluded.

According to the RUV, in 2018 there were 8,808 young people returned or relocated in those three departments (Unidad de Atención y Reparación Integral a las Víctimas [UARIV], 2018). A sample of 369 subjects was selected, according to the representativeness criterion of 5\% maximum admissible error and 95\% confidence. Through non-probabilistic and incidental sampling, 388 participants of legal age were selected, given the self-selection bias that this entails in voluntary participation research (Kerlinger and Lee, 2002). According to gender, which is the only sociodemographic information registered in the RUV (36.67\% men and $60.33 \%$ women), there were no statistically significant differences (with 95\% confidence) between the characteristics of the population and the sample based on it (36.43\% men, 63.57 women; $Z=1.27$ ). The distribution of the subjects was as follows: $35 \%$ of the participants were in Atlántico, $25 \%$ in Cesar, and $41 \%$ in Sucre. $67 \%$ were in a relocation situation, and $33 \%$ in return. The ages were between 17 and 30 years of age $(M=23.5$ and $D=4.183)$ of which, $78 \%$ were between 18 to 25 years, $19 \%$ were between 26 and 30 years.

\section{Technics and Instruments Psychosocial Trauma Scale-ETAPS}

A scale designed and validated with Colombian population by Villagrán (2016), composed of 62 items, which are originally grouped into four factors, namely: (1) the pre-traumatic situation, (2) destruction of sociality (3) personal and collective efficacy and (4) intergroup emotions. Following the recommendation of Villagrán (2016), in the context of the victim population in Colombia, Quintero (2020), (in press) determined the following structure with the same number of items presented as statements: 
(1) pre-traumatic situation, composed of 21 items (for example, "saying what I thought was about to cost me my life"), (2) personal, family, and community destruction, with nine items (for example, "living together with my family has become more difficult every day") (3) disintegration of the inner world, with seven items (for example, "I have no one to count on"), (4) Intergroup emotions, made up of seven items (for example, "there can be no forgiveness for executioners"), (5) expression of emotional ambivalence, with six items (for example, "despite of what happened, I do not lose hope for the future"), (6) recognition of personal abilities, with four items (for example, "I have more confidence in myself") and (7) personal and collective efficacy, composed of eight items (for example, "in my community/neighborhood, the participation of people in community activities has increased"). The response format ranges from 1 = "strongly disagree" to 7 = "strongly agree." According to the analysis carried out on this sample, it can be pointed out that it is a factorially valid $\left[\chi^{2}=6565.07, p\right.$-value $=0.000$, root mean square error approximation (RMSEA) $=0.083$, and adjusted goodness of fit index $($ AGFI $)=0.90]$, and reliable structure ( $\Omega=0.97$ ). The scores were calculated by the refined regression method (DiStefano et al., 2009), for which the standardized scores $(M=0$ and $D=1)$ are presented.

\section{Ryff Scale of Psychological Well-Being}

Scale designed by Ryff (1989), adapted and validated into Spanish by Díaz et al. (2006) composed of 29 items, with six dimensions originally distributed as follows: (1) Self-acceptance, (2) Positive relationships with other people, (3) Autonomy, (4) Environmental Mastery, (5) Purpose in life, and (6) Personal growth. For the context of the population victim of the armed conflict in Colombia, Quintero (2020), (in press) determined the following structure composed of the same number of items presented as affirmations: (1) Self-acceptance, with eight items (for example, For me, the life has been a continuous process of study, change, and growth), (2) ineffective relationships, with seven items (for example, I often feel lonely because I have few close friends with whom to share my concerns), (3) Personal planning, composed of seven items (for example, I enjoy making plans for the future and working to make them come true), (4) Relationships solid / strong interpersonal, with three items (for example, I feel that my friends bring me many things), (5) Selfassertion difficulty with two items (for example, I tend to worry about what other people think of me) and (6) Personal growth was composed of two items (for example, "I think that over the years I have not improved much as a person"). The answer options range from 1 = "strongly disagree" to $6=$ "strongly agree." According to the analyses carried out based on this sample, it can be pointed out: this structure is factorially valid $\left(\chi^{2}=1209.94\right.$, $p$-value $=0.00000$, RMSEA $=0.073$, and AGFI $=0.94)$ and reliable $(\Omega=0.96)$. The scores were calculated by the refined regression method (DiStefano et al., 2009), so the standardized scores $(M=0$ and $D=1$ ) are presented.

\section{The Satisfaction With Life Scale}

Proposed by Diener et al. (1985), SWLS, was adapted and validated into Spanish by Atienza et al. (2000), in a unidimensional way, consisting of five items. For the context of the population victim of the armed conflict in Colombia, Quintero (2020), (in press) determined the following structure composed of the same number of items presented as affirmations: (1) satisfaction with current life, with three items (for example, "the type of life I lead is similar to the type of life I always dreamed of leading") and (2) satisfaction with the past life, with two items (for example, "so far I have obtained the important things I want in life"). The response format goes from $1=$ "strongly agree" to $5=$ "strongly disagree." According to the analyses based on this sample, it can be pointed out that: this structure is factorially valid $\left(\chi^{2}=3.55, p\right.$-value $=0.47$, RMSEA $=0.000$, and AGFI $=0.99)$ and reliable $(\Omega=0.95)$. The scores were calculated by the refined regression method (DiStefano et al., 2009), therefore the standardized scores $(M=0$ and $D=1$ ) are presented.

\section{Social Well-Being Scale}

Constructed by Keyes (1998), and adapted to Spanish by Blanco and Díaz (2005) with 25 items in five dimensions distributed as follows: (1) social integration, (2) social acceptance, (3) social contribution, (4) social actualization, and (5) social coherence. For the context of the population victim of the armed conflict in Colombia, Quintero (2020), (in press) determined the following structure made up of the same number of items presented as statements: (1) social contribution, with eight items (for example, "I feel that I am an important part of my community"); (2) distrust of people, with three items (for example, "I think people are not to be trusted"); (3) anomie, with five items (for example, "many cultures are so strange that I cannot understand them"); and (4) distrust in the society development, with nine items (for example, "for me, social progress is something that does not exist"). The response format goes from $1=$ "strongly agree" to 7 = "strongly disagree." According to the analysis carried out based on this sample, it can be noted: this structure is factorially valid $\left(\chi^{2}=719.43, p\right.$-value $=0.00000$, RMSEA $=0.065$, and AGFI $=0.90)$ and reliable $(\Omega=0.94)$. The scores were calculated by the refined regression method (DiStefano et al., 2009), so the standardized scores $(M=0$ and $D=1)$ are presented.

\section{Sociodemographic Variables Booklet}

It was prepared with the aim of finding out the sociodemographic characteristics of participants: age, sex, educational level, employment status, marital status, situation of comprehensive shelter (return or relocation).

\section{Procedure}

After approval by the Ethics Committee of Universidad Del Norte, the participants were contacted through the professional team of the "Unidad para la atención y reparación a las víctimas" (Unit for Comprehensive Care and Reparation to Victims) of each department (Province), who voluntarily accepted and filled out the informed consent. The application of the booklet was carried out on paper, in the homes of the participants, without a time limit, and was assisted and guided by psychology professionals who were hired and trained on the variables of the study, the proper completion of the booklet, and the 
possible concerns or situations that could arise during the application. At its completion, a snack was given to compensate for their collaboration. Likewise, at the end of the collection of information, with the intention of corresponding ethically with the collaboration of the participants and, in recognition of the problems faced by the study population, workshops were held under the theme of achieving well-being. The application lasted approximately 6 months, after which the organization and information processing continued.

\section{Data Analysis Plan}

It began by confirming the existence of an underlying factorial structure, both in the model that considered the 12 well-being factors, if all the factors underlying each of the three tests used were considered; as in the model composed of only 8 of these factors, following the recommendations of Castellar (2020).

Subsequently, to determine which of the 2 one-dimensional structures should be used, the confirmatory factor analysis was applied, under the strategy of rival models (Hair et al., 2014), in order to determine, if all the scores of factorial factors of the 3 considered tests should be used, or if factors 2 and 3 of Social Well-being (Social Contribution and Distrust in the development of society), and factors 1 and 6 of Psychological Well-being (Selfacceptance and Difficulty for flexibility and obstinacy) should be dispensed of, following the recommendations of Castellar (2020).

Then, for internal consistency, the value of the Omega coefficient $[\Omega]$ was considered, which is the most suitable internal consistency coefficient for tests that were factorially validated (Heise and Bohrnstedt, 1970; McDonald, 1981; Muñiz, 1998; Ercan et al., 2007; Dunn et al., 2014) and higher than 0.70 points, according to the scale described by Prieto and Muñiz (2000) and updated by Hernández et al. (2016a,b). Next, the factorial score of all the participants was calculated, in the factor underlying the three well-being tests, to then analyze their compliance with the assumption of normality through the KolmogorovSmirnov Test $[\mathrm{KS}]$ for a sample, with correction of Lilliefors significance $[\mathrm{K}-\mathrm{SL}]$.

To determine if there is any statistically significant difference between the common factor of general well-being and the factorial scores of psychosocial trauma, the Student's $t$-test was used, whose interpretation was made according to the fulfillment of the homoscedasticity assumption, evaluated through the $p$-value of the Levene statistic. Likewise, to determine the size and magnitude of the effect (1- $\beta$ ), Cohen's d-coefficient was used. Statistical power will be considered adequate, exceeding the $80 \%$ criterion.

The univariate correlation between the Psychosocial Trauma Factors was analyzed with respect to the common factor of general well-being, following the classification described by Prieto and Muñiz (2000), and Hernández et al. (2016a,b), to interpret the predictive relationship between psychological tests. Significance was evaluated with the $95 \%$ confidence criterion ( $\alpha=0.05$ ). For the calculation of the relationship between the psychosocial trauma factors and the underlying general wellbeing, multiple regression was used by the method of steps forward, in order to determine which were the psychosocial trauma factors that were really related to well-being and maintaining compliance with the assumption of absence of multicollinearity, for this, those factors of psychosocial trauma whose tolerance measure was higher than the minimum expected criterion were excluded from the linear model of multiple regression (Minimum tolerance $=0.98$ ). Likewise, compliance with the assumption of absence of multicollinearity was verified from the value of the coefficient of the Durbin-Watson [DW] indicator, which must be between the limits of 1.5 and 2.5 points. Subsequently, the direction of the effect of each of these psychosocial trauma factors incorporated into the multiple linear model were analyzed, based on the analysis of the signs of the regression coefficients $[\beta]$.

In order to know the moderating effect of the returned and relocated variable, a multivariate statistical analysis model was used, which allowed for the estimation of the effect and the relationships between multiple variables. That is, considering that the quality of moderation implies "establishing differential levels of relationship" (Robles, 1997) between the variables, the value of the multiple correlation coefficient between the trauma factors identified in the multiple regression was compared, with respect to the common factor general well-being, but differentiated according to the situation of returnee or relocated; then, the methodology established by Baron and Kenny (1986), and, to determine the type of moderation, the guidelines established by Sharma et al. (1986) were followed and afterward, the magnitude of the differences in the change of the correlations with Cohen's q-statistic, which will suppose a small difference, when its value is less than 0.20 , a large difference, when it exceeds 0.5 points, and a median difference, when it is between both extremes. To estimate the $Z$-value of the differences between correlations, the Fisher Transform indicator was used; which allowed for the establishment of the existence of a statistically significant difference, when the absolute value of the difference exceeds the criterion of 1.96 points, or its $p$-value is less than 0.05 points.

Finally, the existence of the quality of moderation of the situation of returned or relocated was determined from the moderation analysis proposed by Hayes (2018), from the use of the Software Process (Hayes, 2018) that is incorporated into the SPSS. Statistically significant differences (Student's $t$-test) were analyzed between the relocated victims compared to the returnees, in each of the trauma factors that maintain a statistically significant relationship with general well-being. In this way, the trauma factors that have relevant differences with respect to general well-being were determined, either independently of the type of situation (returnee or relocated), or in particular to one of the groups (returnees vs. relocated).

\section{RESULTS}

\section{Construction of the General Well-Being Score and Its Distribution}

The multivariate normality assumption was fulfilled, both in model 1 , of 12 well-being factors $\left(\mathrm{RMK}_{1}=1,189\right)$, and in model 2 , of eight factors $\left(\mathrm{RMK}_{2}=1,167\right)$, suggested by Castellar (2020), (in press) and the existence of an underlying factorial structure will 
be determined in the case of model $2\left(d_{2}=0.504, \mathrm{KMO}_{2}=0.596\right.$ and Bartlett $p$-value $2<0.001)$, but not so in Model $1\left(d_{1}=0.498\right.$, $\mathrm{KMO}_{1}=0.385$ and Bartlett $p$-value $\left.1<0.001\right)$.

According to the value of $\chi^{2}$, Model 2 could be considered as more appropriate than Model $1\left(\chi^{2}\right.$ Model $2=81.95<\chi^{2}$ Model $1=155.08$ ). However, it was not possible to distinguish which of the two models would best fit the data, based on the $p$-value of $\chi^{2}$, since in both cases, the value was $p<0,001$. Although the goodness of fit index (GFI) of Model $2\left(\mathrm{GFI}_{2}=0.95\right)$ was higher than that of Model $1\left(\mathrm{GFI}_{1}=0.94\right)$, its difference was minimal. In the case of RMSEA, it could be determined that there was a better fit in the case of Model $2\left(\mathrm{RMSEA}_{2}=0.089\right)$ compared to Model $1\left(\mathrm{RMSEA}_{1}=0.070\right)$. As with the $p$-value of $\chi^{2}$, it was not possible to determine which model best fit the data based on the RMSEA $p$-value (RMSEA $p$-value ${ }_{1}=0.00640$ and RMSEA $p$-value $\left._{2}=0.0007\right)$. Based on the NCP and the ECV, it could be pointed out again that Model 2 has a better fit to the data $\left(\mathrm{NCP}_{2}=61.950\right.$ and $\left.\mathrm{ECVI}_{2}=0.29\right)$, compared to Model $1\left(\mathrm{NCP}_{1}=101.080\right.$ and $\left.\mathrm{ECVI}_{1}=0.52\right)$. It was not possible to determine the model with the best fit based on the AGFI, since the value was the same in both $\left(\mathrm{AGFI}_{1}=0.91\right.$ and $\left.\mathrm{AGFI}_{2}=0.91\right)$. Finally, it was also concluded that Model 2 had a better fit to the data than Model 1, based on parsimony normed fit index $(\mathrm{PNFI})\left(\mathrm{PNFI}_{1}=0.15 ; \mathrm{PNFI}_{2}=0.5\right)$, but not with the parsimony goodness of fit index $(\mathrm{PGFI})\left(\mathrm{PGFI}_{1}=0.65 ; \mathrm{PGFI}_{2}=0.53\right)$. Model 2 , in addition to being structurally valid, has adequate internal consistency $(\Omega=0.776)$. All of the above allowed determining that Model 2 was the one that best fit the data collected in the three well-being instruments, and whose representation is presented in Figure 1.

Model 2 is made up of: from Factor 1 of Social Well-being, distrust in people [V1] and anomie [V2]. From Satisfaction with Life, there is satisfaction with current life [V3] and with past life [V4]; and Psychological Well-being, there is Factor 2 of ineffective relationships [V5], Factor 3 of planning life [V6], Factor 4 of solid/strong interpersonal relationships [V7], and Factor 5 on self-affirmation difficulty [V8].

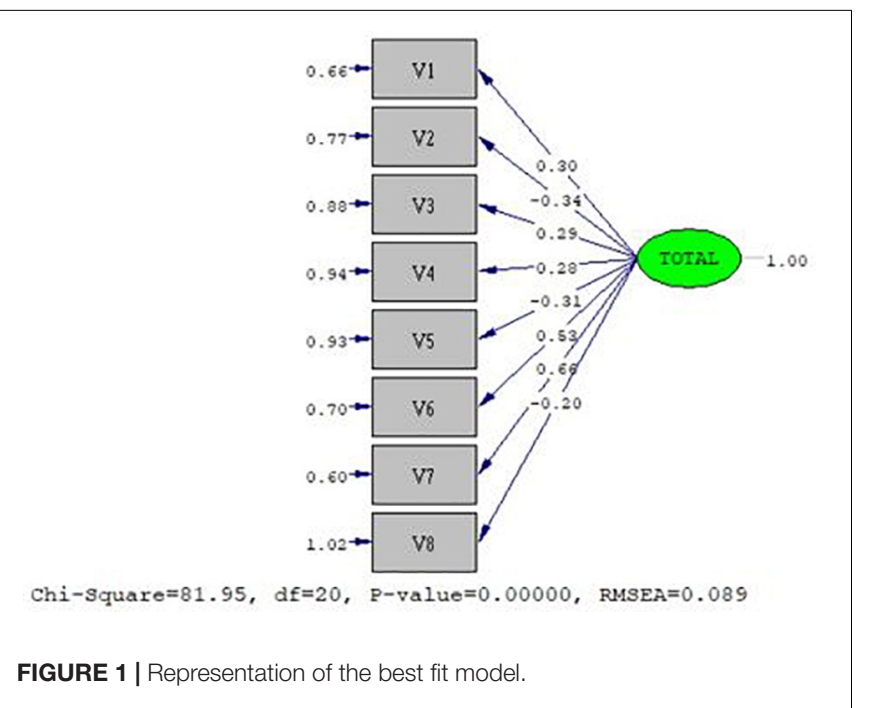

The shape of the distribution of this underlying measure of common general well-being (see Figure 2), assumes that its range covers the scores of -3.42 as a minimum value and a maximum of 2.25 , with an average of $p<0,001$ and a deviation of 1.00 , which assumes that it is a standardized distribution that is also normal $\left(\mathrm{K}-\mathrm{S}_{L}=0.05\right)$.

\section{Comparing Returnees and Relocated With General Well-Being}

Differences $(t=-4.35)$ are statistically significant $(p$ value $<0.001)$, moderate $\left(d_{\text {Cohen }}=0.465\right)$ and strong $(1-\beta=0.996)$ in favor of returnees $\left(X_{\text {Returnees }}=0.31\right.$; $\left.S_{\text {returnees }}=1.01\right)$, in comparison with the relocated $\left(X_{\text {Relocated }}=-0.15 ; S_{\text {relocated }}=0.96\right)$, after having estimated these differences, considering compliance with the homoscedasticity assumption $($ F-Levene $=0.63 ; p$-value $=0.43$ ).

\section{Comparing Returned and Relocated With Psychosocial Trauma Factors}

In Table 1, statistically significant differences are observed between the situation of returnees vs. relocated between: (1) pre-traumatic situation $\left(p\right.$-value $<0.001, d_{\text {Cohen }}=0.39,1$ $\beta=0.98)$, (2) disintegration of the inner world ( $p$-value $<0.001$, $\left.d_{\text {Cohen }}=0.41,1-\beta=0.98\right),(3)$ intergroup emotions $(p-$ value $\left.<0.001, d_{\text {Cohen }}=0.73,1-\beta=1.00\right)$, (4) expression of emotional ambivalence $\left(p\right.$-value $<0.001, d_{\text {Cohen }}=0.35$, $1-\beta=0.95)$, and (5) personal and collective efficacy ( $p$ value $<0.001, d_{\text {Cohen }}=0.44,1-\beta=0.99$ ); which would suppose that to the extent that a participant belonged to the group of returned victims, a higher score would be expected for: pretraumatic Situation $\left(X_{\text {Returnees }}=0.23 ; S_{\text {returnees }}=0.94\right)$, intergroup emotions $\left(X_{\text {Returnees }}=0.45 ; S_{\text {returnees }}=0.91\right)$, and personal and collective efficacy $\left(X_{\text {Returnees }}=0.31 ; S_{\text {Returnees }}=0.93\right)$, while it is expected to have a lower score of: disintegration of the inner world ( $\left.X_{\text {Returnees }}=-0.25 ; S_{\text {returnees }}=0.78\right)$ and expression of emotional ambivalence $\left(X_{\text {Returnees }}=-0.22 ; S_{\text {returnees }}=0.99\right)$; on the other hand, if it belonged to the group of relocated victims, an opposite pattern would be expected in all these variables. Finally, no differences are observed between the measure of comprehensive reparation of the participants and the factors of personal, family, and community destruction $(p$-value $=0.18$; $\left.d_{\text {Cohen }}=0.14 ; 1-\beta=0.37\right)$, and recognition of personal capacities $\left(p\right.$-value $\left.=0.95 ; d_{\text {Cohen }}=0.01 ; 1-\beta=0.06\right)$.

\section{Correlation Between General Well-Being and Psychosocial Trauma Factors}

It can be seen in Table 2, that the correlation between wellbeing and trauma factors are significant with an adequate score in 3 of them: personal, family and community destruction $(r=-0.354 ; p$-value $<0.001)$, disintegration of the inner world $(r=-0.393 ; p$-value $<0.001)$ with a negative score, and personal and collective efficacy $(r=0.357$; $p$-value $=0.000)$ with a positive score. A sufficient relationship was also observed, but a little weaker, in the recognition of personal capacities $(r=0.203 ; p$-value $<0.001)$. It is also observed that the direction observed in these relationships is coherent, since 


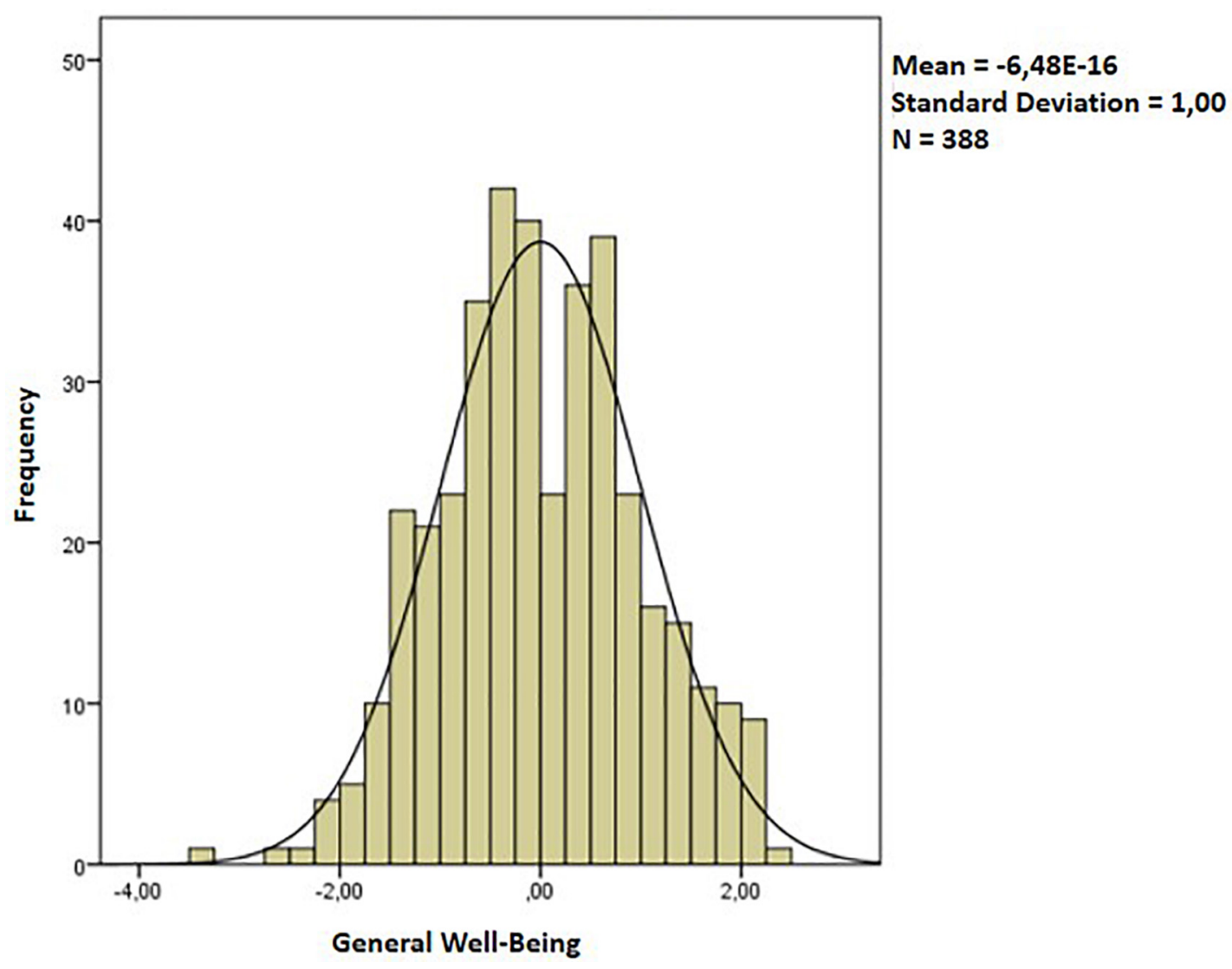

FIGURE 2 | Distribution of the general well-being measure.

the higher the score in the personal, family, and community destruction and in the disintegration of the inner world, the lower the common general well-being score and the higher the score in the recognition of personal capacities and personal and collective efficacy, the greater common general well-being there will be. Likewise, it is observed that pre-traumatic situation $(r=0.008$; $p$-value $=0.882)$ and intergroup emotions $(r=-0.086 ; p$-value $=0.092)$, maintain weak relationships, which are not statistically significant with general well-being, while the expression of emotional ambivalence $(r=-0.119$; $p$-value $=0.019)$, maintains a weak relationship, although statistically significant, with this same measure.

\section{Multiple Regression Between General Well-Being and Psychosocial Trauma Factors}

The multiple relationship between the component factors of trauma and the general measure of well-being suppose an excellent and statistically significant relationship $(R=0.689$; $p$-value $<0.001)$. This relationship supposes the fulfillment of the assumption of independence between the predictor variables $(\mathrm{DW}=1.866)$. The following factors were excluded from this multiple linear model: (1) pre-traumatic situation and (2) intergroup emotions.
As seen in Table 3, the interpretation of the direction of the effects of each trauma factor is maintained, with respect to its prediction on the common factor of general wellbeing that was observed in Table 2 (bivariate); in this sense, the factors of personal, family, and community destruction; disintegration of the inner world; and expression of emotional ambivalence maintain an inverse relationship with the common factor of general well-being, while the factors recognition of personal abilities, and personal and collective efficacy maintain a direct relationship. In this table, it is also observed that the tolerance of these factors exceeds the minimum criterion of 0.98 points.

\section{Quasi-Moderating Effect of the Situation of Return or Relocation With Psychosocial Trauma and General Well-Being}

With regard to the quality of moderation of the return or relocation situation, an excellent statistically significant correlation was observed, both in the group of relocated participants $(R=0.615 ; p$-value $<0.001)$ and in the returnees $(R=0.782 ; p$-value $<0.001)$.

According to the moderation analysis (Hayes, 2018), it was possible to determine that there is no pure moderation effect 


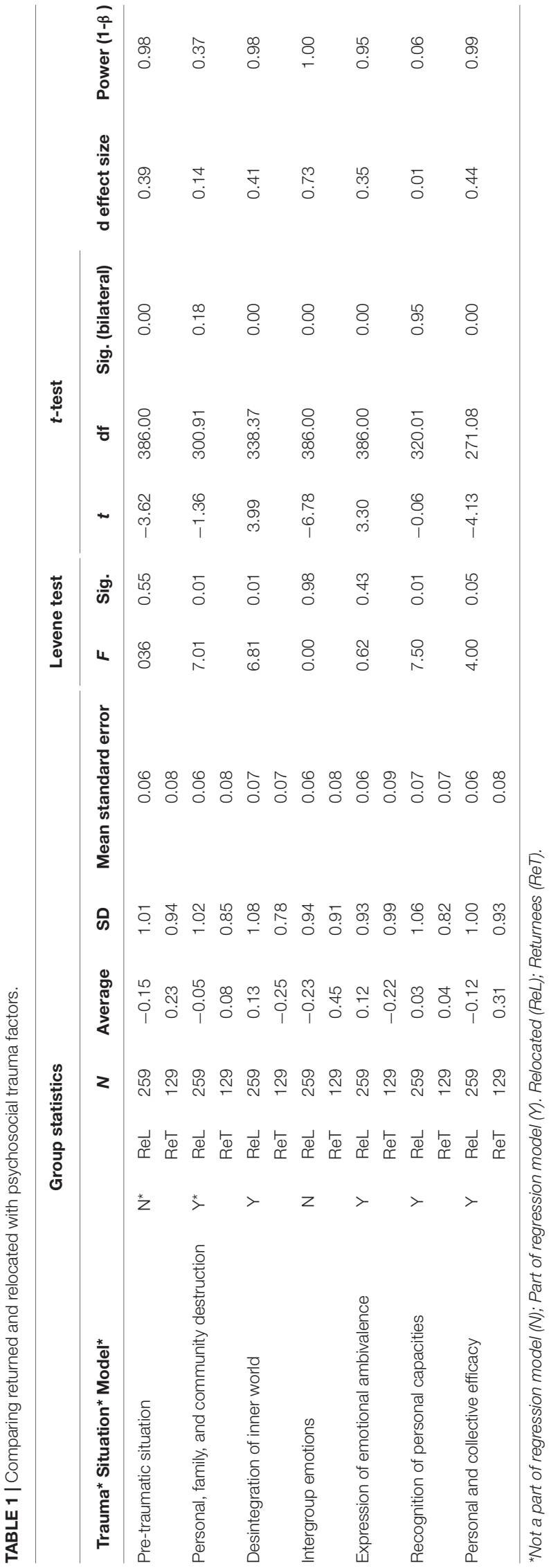

between the psychosocial trauma factors $(\beta=0.66 ; t=16.26$; $p$-value $=0.000)$, and the returnee or relocated situation $(\beta=-8.58 ; t=-2.11 ; p$-value $=0.035)$ with respect to general well-being, since their interaction was not significant $(\beta=0.146 ; t=1.793 ; p$-value $=0.074)$. However, when analyzing the difference between both correlation coefficients, it could be observed that it was intermediate $\left(q_{\text {Cohen }}=0.334\right)$, statistically powerful $(1-\beta=0.922)$, and significant $(Z=3.014$; $p$-value $=0.002)$, so it could be determined that the situation of returnee or relocated is a quasi-moderating variable (Sharma et al., 1986), since: (1) the situation of returnee or relocated of the participants, with respect to trauma factors was sufficient $(R=0.202)$ and statistically significant $(p$-value $=0.000)$ and $(2)$ the situation of return or relocation of the participants, has a sufficient $(R=0.216)$ and statistically significant $(p$-value $=0.000)$ relationship with general well-being. Therefore, the situation of returnee or relocated could be classified as a quasi-moderating variable (Sharma et al., 1986) of the relationship between the statistical combination of psychosocial trauma factors and the common factor of general well-being.

The above, together with the information in Table 3 (If $\beta_{\text {Tabla3 }}>0 \rightarrow$ Reinforce; If $\beta_{\text {Tabla } 3}<0 \rightarrow$ Extinguish) and $X_{\text {Relocated }}=-0.15 ; S_{\text {relocated }}=0.96 ; t=-4.35 ; p$-value $=0.000$; $d_{\text {Cohen }}=0.46$, allows for the determination of the trauma factors that should be intervened to improve the scores of the common factor of the general well-being of the victims of the Colombian armed conflict, regardless of whether the participant is relocated or returned ( $p$-value $>0.05$ and $\mathrm{d}_{\text {Cohen }}<0.20$ ), or, specifically about the relocated group, who have the lowest average score.

According to the above, it is necessary to reduce the effects of personal, family, and community destruction $\left(\beta_{\text {Tabla } 3}=-0.38\right.$; $p$-value $=0.18$; and $d_{\text {Cohen }}=0.14$ ) while it is necessary to reinforce the effects of recognition of personal capabilities $\left(\beta_{\text {Tabla } 3}=0.23\right.$; $p$-value $=0.95$; and $d_{\text {Cohen }}=0.01$ ), in all participants, to improve their general well-being. On the other hand, for the relocated, it is necessary to strengthen personal and collective efficacy $\left(\beta_{\text {Tabla3 }}=0.34 ; X_{\text {Relocated }}=0.31 ; S_{\text {relocated }}=0.93 ; t=-4.13 ;\right.$ $p$-value $=0.00$; and $\left.d_{\text {Cohen }}=0.44\right)$, and reduce the disintegration of the inner world $\left(\beta_{\text {Tabla3 }}=-0.41 ; X_{\text {Relocated }}=-0.25\right.$; $S_{\text {relocated }}=0.78 ; t=3.99 ; p$-value $=0.00 ;$ and $\left.d_{\text {Cohen }}=0.41\right)$ and expression of emotional ambivalence $\left(\beta_{\text {Tabla3 }}=-0.13\right.$; $X_{\text {Relocated }}=-0.22 ; S_{\text {relocated }}=0.99 ; t=3.30 ; p$-value $=0.00$; and $d_{\text {Cohen }}=0.35$ ), to improve their general well-being.

\section{DISCUSSION}

Well-being and psychosocial trauma in returnees and relocated are significantly different, so the hypothesis was not tested because there was no moderation, but rather quasi-moderation. General well-being (Summerfield, 2001; Lazarus, 2003; Keyes, 2005; Díaz et al., 2007; Castellar, 2020, in press) is higher in returnees, which is consistent with previous studies (Bozzoli et al., 2012; Ramírez, 2015; Arévalo, 2016; Mejía, 2019) who affirm that the construction of memory, social, and cultural identity at the scene of the events is essential for their well-being. This same process can be more difficult for the relocated, which makes 
TABLE 2 | Correlation between general well-being and psychosocial trauma factors.

\begin{tabular}{|c|c|c|c|c|c|c|c|}
\hline & $\begin{array}{c}\text { Pre-traumatic } \\
\text { situation }\end{array}$ & $\begin{array}{l}\text { Personal, } \\
\text { family, and } \\
\text { community } \\
\text { destruction }\end{array}$ & $\begin{array}{l}\text { Desintegration } \\
\text { of inner world }\end{array}$ & $\begin{array}{l}\text { Intergroup } \\
\text { emotions }\end{array}$ & $\begin{array}{c}\text { Expression of } \\
\text { emotional } \\
\text { ambivalence }\end{array}$ & $\begin{array}{l}\text { Recognition } \\
\text { of personal } \\
\text { capacities }\end{array}$ & $\begin{array}{c}\text { Personal and } \\
\text { collective } \\
\text { efficacy }\end{array}$ \\
\hline Pearson correlation & 0.008 & -0.354 & -0.393 & -0.086 & -0.119 & 0.203 & 0.357 \\
\hline Sig. (bilateral) & 0.882 & 0.000 & 0.000 & 0.092 & 0.019 & 0.000 & 0.000 \\
\hline
\end{tabular}

TABLE 3 | Multiple regression between general well-being and psychosocial trauma factors.

\begin{tabular}{|c|c|c|c|c|c|c|c|c|}
\hline & \multicolumn{2}{|c|}{$\begin{array}{l}\text { Non-standardized } \\
\text { coefficients }\end{array}$} & \multirow[b]{2}{*}{$t$} & \multirow[b]{2}{*}{ Sig. } & \multicolumn{2}{|c|}{ Collinearity statistics } & \multirow[b]{2}{*}{$\begin{array}{c}\Delta \text { Returnee } \\
\text { vs. Relocated }\end{array}$} & \multirow[b]{2}{*}{$\begin{array}{l}\text { Group with higher } \\
\text { well-being }\end{array}$} \\
\hline & Beta & $\begin{array}{l}\text { Standard } \\
\text { error }\end{array}$ & & & Tolerance & VIF & & \\
\hline (Constant) & -0.01 & 0.037 & -0.371 & 0.711 & & & & \\
\hline Desintegration of inner world & -0.41 & 0.037 & -11.109 & 0.000 & 0.995 & 1.005 & $-0.25^{\star}$ & Returnees \\
\hline Expression of emotional ambivalence & -0.13 & 0.038 & -3.294 & 0.001 & 0.999 & 1.001 & $-0.22^{*}$ & Returnees \\
\hline Personal and collective efficacy & 0.34 & 0.037 & 9.062 & 0.000 & 0.995 & 1.005 & $0.31^{\star}$ & Relocated \\
\hline Personal, family, and community destruction & -0.38 & 0.038 & -9.954 & 0.000 & 0.996 & 1.004 & 0.08 & Both \\
\hline Recognition of personal capacities & 0.23 & 0.038 & 6.130 & 0.000 & 0.989 & 1.011 & 0.04 & Both \\
\hline
\end{tabular}

${ }^{*}$ Significative difference. ${ }^{* *}$ Check the mean between the situation between returnees and relocated with general well-being.

them always feel displaced because they are in a place that is not their home (Palacio et al., 2003), maintaining a nostalgia for the past and a longing for what they were in their land. What about their life projects? How do they integrate into their new lives? Integration with their community is likely to overshadow the possible difficulties for returnees.

Following this argument, although a moderating effect was not observed, a quasi-moderating effect was observed due to the situation of returning or relocating, in the relationship between the factors of psychosocial trauma and well-being, which is corroborated by the statistically significant differences and mean size found when comparing the correlation coefficients of both groups. This means that the psychosocial trauma factors (disintegration of the inner world, personal, family, and community destruction, personal and collective efficacy, recognition of personal capacities, and expression of emotional ambivalence), however, they had a different relationship strength depending on the group they belong to: returnees or relocated.

In general terms, it was observed that to the extent that a person has a lower score in: disintegration of the inner world; personal, family, and community destruction; and expression of emotional ambivalence at the same time that they have higher scores of personal and collective efficacy, and recognition of personal abilities will have a higher overall wellness score. Notwithstanding the above, it will be stronger in the group of returnees in the following variables: disintegration of the inner world, and expression of emotional ambivalence. Although in the group of relocated it will be in the variable of: personal and collective efficiency. With this we contribute two new visions to the phenomenon of return and relocation in young people: (1) The facts and personal, family, and community experiences of both groups of young people have not been destroyed as previously thought, and (2) It is possible to recognize the personal capacities of young people in the environment they live in (be it returned or relocated). This is likely because young people have not been direct witnesses to the violence, leading them to perceive the situation of return or relocation as an opportunity to strengthen their personal, family, and community life. This result agrees with the exclusion of the pre-traumatic situation factor from the regression model for both groups.

Regarding the relationship between disintegration of the inner world and expression of emotional ambivalence in the general well-being of returnees, Ibáñez and Querubín (2004) showed that young people could consider a better experience of wellbeing in relocation, since they could have more opportunities of personal and social development. In contrast, the present study reveals that an adequate structure of attitudes and emotions associated with the experience of return shows in young people a significant indicator to maintain a high well-being, so that less destruction of the inner world will affect a greater well-being, contrary to what may happen to the relocated. Regarding the expression of emotional ambivalence, it is already confirmed by the General Report of the National Center for Historical Memory (Centro Nacional de Memoria Histórica, 2013) and in the study by Brewin et al. (1996), in which violent events are clear examples of traumatic experiences that they tend to destroy the belief, control, and meaning system, however, we propose that although they have marked their life, returning to their place of origin facilitates the recovery of their cognitive belief system, since it allows them to return to the way of life prior to displacement and with it increase their well-being.

Contrary to what is proposed by Hernández (2010), who compiles unemployment, precarious living conditions, and stigmatization for being victims in the stories of the relocated, this study reveals that despite the painful experience of displacement 
and the countless changes brought about by relocation, relocating has been able to change their personal and social life, recognizing that they are useful and effective. This is shown in their active participation in community activities, feeling a part of it.

In conclusion, psychosocial trauma cannot be defined outside of the historical and social context that surrounds it (Martín Baró et al., 1990), return and relocation have a particular power to shape the life history of human beings who choose it, perhaps as the institutional way to repair, but also for the motivation pursued every day to bring in a better well-being. Given that the study participants are young, the development of personal and collective capacities as a function of the constant search for their own well-being and that of their family is surprising, in the case of returnees, for example. This is a unique finding in this study, because the scientific generality addressed so far has shown the opposite (Haroz et al., 2013; Huser et al., 2019; Sullivan, 2019). In the relocated youth, despite the fact that they build a personal and social life, this is not enough to achieve high well-being, it seems that the effort to be made is greater than in the returnees.

As limitations of the study, it is necessary to mention that for this type of situation, it is difficult to carry out experimental studies given the difficulty in the ethical manipulation of the variables, and because of access to the participants. We realize that there are also limitations in the information available in the databases of the organizations that work with this population. Furthermore, it is necessary, for future studies, to take into account the following variables: (1) Travel time, return and relocation time. (2) Population indicators such as educational level, type of reparation (if relocated or returned). (3) Intensity of the victimizing acts (being threatened, beaten or injured, being a direct witness to murders, etc.). (4) Dearth of scientific studies on the effects of return and relocation in Colombia.

From the point of view of ensuring better precision in the prediction of well-being, it is recommended to continue with the study of other variables that make it possible to better predict the well-being of the relocated, such as the time spent at the relocation site or their sense of community. Social identity and memory would contribute greatly to know the process of rebuilding its social fabric. On the other hand, resilience and post-traumatic growth would be convenient to verify positive experiences that may be associated with overcoming trauma. In addition to psychosocial trauma, the variable of transgenerational transmission of trauma must be considered, since the intensity of memories of the experience of violence in the population participating in this study may influence this variable. It is also recommended to consider the variable length of stay for returnees, since it may be relevant to their wellbeing. This undoubtedly motivates the authors to carry out future research.

With a view toward a psychosocial intervention, a guide is proposed to the people in charge of its application to make decisions about the advantage of being able to propose strategies for return or permanence according to the general profile of the victims. The intervention would be more costly in the relocated than in the returnees, not only because their well-being is lower, but the variables that are related to it are less precise in this group. A variable that could be reinforced in young returnees with low levels of well-being would be personal and collective efficacy, through actions that lead to social skills training, for example. On the contrary, the intervention in the relocated youth would focus on minimizing the disintegration of the inner world and the expression of emotional ambivalence in order to maintain their personal and collective efficacy. For both groups, it is necessary to join forces in proposing activities that allow maintaining the experiences associated with the recognition of their personal capacities and reducing those associated with personal, family, and community destruction. Even though there was a statistically significant difference between returnees and relocated in the pretraumatic situation factors and intergroup emotions, having not entered the regression models, no intervention planning based on these factors is justified, given that even when there are differences between groups, it does not generate any contribution to general well-being. The updating of public policies arises as a reflection on these results. An effort to redirect the focus of return and relocation programs as comprehensive reparation measures could have a better sustainable effect on the well-being of the participants.

\section{DATA AVAILABILITY STATEMENT}

The original contributions presented in the study are included in the article/supplementary material, further inquiries can be directed to the corresponding author/s.

\section{ETHICS STATEMENT}

The studies involving human participants were reviewed and approved by Comité de Ética en investigación de la División Ciencias de la Salud de la Universidad del Norte. The patients/participants provided their written informed consent to participate in this study.

\section{AUTHOR CONTRIBUTIONS}

AM, SQ-G, CM-O, and JP-S contributed to the conception and design of the study. SQ-G organized the database. AM performed the statistical analysis. SQ-G and DC-J wrote the first draft of the manuscript. All authors contributed to the article and approved of the presented version.

\section{FUNDING}

This article is the product of the doctoral research "Analytical Model of the Functional Relations of Social Capital, Mental Health, Individual Coping, and Psychosocial Trauma in Young Victims of the Armed Conflict in the Process of Returning and Relocating in Colombia" funded by the Ministry of Science, 
Technology and Innovation within the framework of the doctoral scholarship of Call 647 of 2014-National Doctorates and the Universidad del Norte de Colombia.

\section{ACKNOWLEDGMENTS}

We thank the editors for taking the time to evaluate our work. We appreciate your remarkable collaboration, support,

\section{REFERENCES}

Abello-Llanos, R., Amaris, M., Blanco, A., Madariaga, C., Manrique, K., Martinez, M., et al. (2009). Bienestar y trauma en personas adultas desplazadas por la violencia política. Univ. Psychol. 8, 455-470.

Alto Comisionado de las Naciones Unidas para los Refugiados [ACNUR] (2019). Tendencias Globales Desplazamiento Forzado en 2018. Geneva: ACNUR.

Amaris, M., Madariaga, C., Blanco, A., Blanco, R., Valle, M., Acuña, E., et al. (2019). Intervenir Para Reparar: Recuperación de la Dignidad y la Salud Mental en Contextos de Violencia. Colombia: Universidad del Norte.

American Psychiatric Association [APA] (2013). DSM-5 Diagnostic and Statiscal Manual of Mental Disorder. Washington DC: American Psychiatric Publishing. doi: 10.1176/appi.books.9780890425596

Arango, M., and Arroyave, O. (2017). Proceso de cohesión social en dos poblaciones retornadas en el Departamento de Antioquia (Colombia), Dabeiba y Nariño. Rev. CES Psico 10, 86-102. doi: 10.21615/cesp.10.2.6

Arendt, H. (2005). Sobre la Violencia. Madrid: Alianza Editorial.

Arévalo, M. (2016). La reubicación como proceso de desterritorialización. Polit. Cult. Prima. 45, 153-180.

Aristizábal, E., Palacio, J., Madariaga, C., Osman, H., Parra, L. H., Rodríguez, J., et al. (2012). Síntomas y traumatismo psíquico en víctimas y victimarios del conflicto armado en el Caribe colombiano. Psicol. desde el Caribe 29, 123-152.

Atienza, F. L., Pons, D., Balaguer Solá, I., and García-Merita, M. (2000). Propiedades psicométricas de la escala de satisfacción con la vida en adolescentes. Psicothema 12, 314-319.

Baron, R. M., and Kenny, D. A. (1986). The moderator-mediator variable distinction in social psychological research: conceptual, strategic, and statistical considerations. J. Pers. Soc. Psychol. 51, 1173-1182. doi: 10.1037/0022-3514.51. 6.1173

Bell, V., Méndez, F., Martínez, C., Palma, P. P., and Bosch, M. (2012). Characteristics of the Colombian armed conflict and the mental health of civilians living in active conflict zones. J. Conflict Health 6, 1-8. doi: 10.1186/ 1752-1505-6-10

Black, R., and Gent, S. (2006). Sustainable return in post-conflict contexts. Int. Migrat. 44, 1-24. doi: 10.1111/j.1468-2435.2006.00370.x

Blanco, A., Blanco, R., and Díaz, D. (2016). Social (Dis) order and psychosocial Trauma: look earlier, look outside and look beyond the persons. Am. Psychol. 71, 187-198. doi: 10.1037/a0040100

Blanco, A., and Díaz, D. (2005). El bienestar social: Su concepto y medición [Social well-being: theoretical structure and measurement]. Psicothema 17, 582-589.

Blanco, A., Díaz, D., and del Soto, A. (2014). Recovering the context in posttraumatic stress disorder: the psychosocial trauma in victims of political violence and terrorism. Estud. Psicol. 27, 333-350. doi: 10.1174/ 021093906778965053

Bohigas, J., Carrillo, J., Garzón, D., Ramírez, M., and Rodríguez, N. (2015). Trauma histórico. Revisión sistemática de un abordaje diferente al conflicto armado. Rev. Colomb. Psiquiatr. 44, 41-49. doi: 10.1016/j.rcp.2014.09.005

Bozzoli, C., Brück, T., and Muhumuza, T. (2012). Movers or Stayers? Understanding the Drivers of IDP Camp Decongestion During Post-Conflict Recovery in Uganda. Berlin: DIW. doi: 10.2139/ssrn.2030822

Brewin, C., Dalgleish, T., and Joseph, S. (1996). A dual representation theory of posttraumatic stress disorder. Psychol. Rev. 103, 670-686. doi: 10.1037/0033295X.103.4.670

Burns, R., Wickramage, K., Anwar, M., Siriwardhana, C., and Checchi, F. (2018). Health status of returning refugees, internally displaced persons, and the host and contributions that have undoubtedly provided great improvements to the outcome of our intellectual product. The results presented in this work are found in the doctoral thesis "Analytical Model of the Functional Relations of Social Capital, Mental Health, Individual Coping, and Psychosocial Trauma in Young Victims of the Armed Conflict in the Process of Returning and Relocating in Colombia" and in the Master's degree thesis "Validation of the General Well-being Score" in pre-printed version.

community in a post-conflict district in northern Sri Lanka: a cross-sectional survey. Conflict Health 12:41. doi: 10.1186/s13031-018-0176-7

Campo-Arias, A., and Herazo, E. (2014). Estigma y salud mental en personas víctimas del conflicto armado interno colombiano en situación de desplazamiento forzado. Rev. Colomb. Psiquiat. 43, 212-217. doi: 10.1016/j.rcp.2014.09.004

Cardozo Rusinque, A., Cortés-Peña, O., and Castro Monsalvo, M. (2017). Relaciones funcionales entre salud mental y capital social en víctimas del conflicto armado y personas en situación de pobreza. Interdisciplinaria 34, 235-257. doi: 10.16888/interd.2017.34.2.1

Castellar, D. (2020). Validación del Puntaje de Bienestar General. [Tesis de maestría]. Barranquilla, ATL: Universidad Del Norte.

Centro Nacional de Memoria Histórica (2013). ¡BASTA YA! Colombia: Memorias de Guerra y Dignidad. Informe General Grupo de Memoria Histórica. Bogotá: Imprenta Nacional.

Charry-Lozano, L. (2016). Impactos psicológicos y psicosociales en víctimas sobrevivientes de masacre selectiva en el marco del conflicto Suroccidente Colombiano en el año 2011. Colomb. Forense 3, 53-62. doi: 10.16925/cf.v3i2. 1756

Chávez, Y., and Falla, U. (2005). Representaciones sociales acerca del retorno en población en situación de desplazamiento asentada en el municipio de soacha. Tab. Rasa 3, 271-292. doi: 10.25058/20112742.238

Chía-Chávez, E., Bilbao, M. A., Páez, D., Iraurgi, I., and Martín-Beristain, C. (2011). "La importancia de los eventos traumáticos y su vivencia: el caso de la violencia colectiva," in Superando la Violencia Colectiva y Construyendo Cultura de Paz, eds D. Páez, C. Martín-Beristain, J. L. González-Castro, N. Basabe, and J. de Rivera (Madrid: Editorial Fundamentos).

Correa De Andreis, A. (2009). "La configuración del proceso de desplazamiento forzado - reasentamiento," in Desplazamiento Interno Forzado Restablecimiento de lo Urbano e Identidad Social, eds A. Correa, S. Jimenez, M. Diaz, and J. Palacio (Barranquilla: Ediciones Uninorte), 71-101.

De Smet, S., Rousseauc, C., Stalpaert, C., and De Haenea, L. (2019). A qualitative analysis of coping with trauma and exile in applied theatre with Syrian refugees: the role of within-group interactions. Arts Psychother. 66:101587. doi: 10.1016/ j.aip.2019.101587

Díaz, D., Blanco, A., Horcajo, J., and Valle, C. (2007). La aplicación del modelo del estado completo de salud al estudio de la depresión. Psicothema 19, 286-294.

Díaz, D., Rodríguez-Carvajal, R., Blanco, A., Moreno-Jiménez, B., Gallardo, I., Valle, C., et al. (2006). Adaptación española de las escalas de bienestar psicológico ryff. Psicothema 18, 572-577.

Diener, E. (1984). Subjective well-being. Psychol. Bull. 95, 542-575. doi: 10.1037/ 0033-2909.95.3.542

Diener, E., and Diener, M. (1995). Cross-cultural correlates of life satisfaction and self-esteem. J. Pers. Soc. Psychol. 68, 653-663. doi: 10.1037/0022-3514.68.4.653

Diener, E., Emmons, R. A., Larsen, R. J., and Griffin, S. (1985). The satisfaction with life scale. J. Pers. Assess. 49, 71-75. doi: 10.1207/s15327752jpa4901_13

DiStefano, C., Zhu, M., and Mîndrilã, D. (2009). Understanding and using factor scores: considerations for the applied researcher. Pract. Assess. Res. Eval. 14:20. doi: $10.7275 /$ da8t-4g52

Dunn, T., Baguley, T., and Brunsden, V. (2014). From alpha to omega: a practical solution to the pervasive problem of internal consistency estimation. Br. J. Psychol. 105, 399-412. doi: 10.1111/bjop.12046

Ercan, I., Yazici, B., Sigirli, D., Ediz, B., and Kan, I. (2007). Examining cronbach alpha, theta, omega reliability coefficients according to sample size. J. Modern Appl. Stat. Methods 6, 291-303. doi: 10.22237/jmasm/1177993560 
Freud, S. (1948). La Histeria, en Obras Completas. Madrid: Editorial Biblioteca Nueva.

Garzón, M. (2011). Ampliando el campo. Estado de la cuestión de la literatura dedicada al tema de retorno de población en situación de desplazamiento. En Boletín de Antropología. Universidad de Antioquia. Medellín. 25, 11-35.

Hair, J., Black, W., Babin, B., and Anderson, R. (2014). Multivariate Data Analysis, 7th Edn. Edinburgh Gate: Pearson Education.

Haroz, E., Murray, L., Bolton, P., Betancourt, T., and Bass, J. (2013). Adolescent resilience in northern uganda: the role of social support and prosocial behavior in reducing mental health problems. J. Res. Adoles. 23, 138-148. doi: 10.1111/j. 1532-7795.2012.00802.x

Hayes, A. (2018). Introduction to Mediation, Moderation and Conditional Process Analysis. New York, NY: The Guilford Press.

Heise, D., and Bohrnstedt, G. (1970). Validity, invalidity, and reliability. Sociol. Methodol. 2, 104-129. doi: 10.2307/270785

Hernández, A., Ponsoda, V., Muñiz, J., Prieto, G., and Elosua, P. (2016b). Revisión del modelo para evaluar la calidad de los tests utilizados en España. Papeles del Psicól. 37, 192-197.

Hernández, A., Ponsoda, V., Muñiz, J., Prieto, G., and Elosua, P. (2016a). Cuestionario de Evaluación de Tests Revisado (CET-R). Available online at: http://www.cop.es/uploads/pdf/CET-R.pdf

Hernández, L. (2010). Procesos de Retorno y Reubicación de dos Comunidades Victimizadas Por el Desplazamiento Forzado en los Montes de María. Actores Sociales y Proyectos Políticos. Trabajo de Grado de la Maestría en Estudios Políticos. Iepri: Universidad Nacional de Colombia.

Hides, L., Quinn, C., Stoyanov, S., Cockshaw, W., Mitchell, T., and Kavanagh, D. (2016). Is the mental wellbeing of young Australians best represented by a single, multidimensional or bifactor model. Psychiatry Res. 241, 1-7. doi: 10.1016/j.psychres.2016.04.077

Huser, C., Cunningham, A., Kamau, C., and Obara, M. (2019). Los retornos de los sursudaneses: percepciones y respuestas. Forced Migrat. Rev. 62, 7-10.

Ibáñez, A., and Querubín, P. (2004). Acceso A Tierras Y Desplazamiento Forzado En Colombia. DOCUMENTO CEDE 2004-23. Available online at: http://static.iris. net.co/semana/upload/documents/Doc-1761_2008926.pdf (accessed June 30, 2020).

Internal Displacement Monitoring Centre [IDMC] (2020). THE DISPLACEMENT CONTINUUM The Relationship Between Internal Displacement and CrossBorder Movement in Seven Countries. Thematic Series the Invisible Majority. Geneva: Internal Displacement Monitoring Centre.

Kerlinger, F., and Lee, H. (2002). "Investigación no experimental," in Investigación del Comportamiento. Métodos de Investigación en Ciencias Sociales, eds F. En Kerlinger and H. Lee (México: McGrawHill), 503-518.

Keyes, C. L. M. (1998). Social well-being. Soc. Psychol. Q. 61, 121-140. doi: 10.2307/ 2787065

Keyes, C. L. M. (2005). Mental illness and/or mental health? Investigating axioms of the complete state model of health. J. Consult. Clin. Psychol. 73, 539-548. doi: 10.1037/0022-006X.73.3.539

Keyes, C. L. M., Shmotkin, D., and Ryff, C. D. (2002). Optimizing well-being: the empirical encounter of two traditions. J. Pers. Soc. Psychol. 82, 1007-1022. doi: 10.1037/0022-3514.82.6.1007

Kokko, K., Korkalainen, A., Lyyra, A.-L., and Feldt, T. (2013). Structure and continuity of well-being in mid-adulthood: a longitudinal study. Journal of Happiness Studies 14, 99-114. doi: 10.1007/s10902-011-9318-y

Lazarus, R. (2003). The lazarus manifesto for positive psychology and psychology in general. Psychol. Inq. 14, 173-189.

Ley de 1448 (2011). Por la Cual se Dictan Medidas de Atención, Asistencia y Reparación Integral a las Víctimas del Conflicto Armado Interno y se Dictan Otras Disposiciones. Bogotá: El Congreso de Colombia.

Ley de 387 (1997). Del Desplazado Y De La Responsabilidad Del Estado. Bogotá: El Congreso de Colombia.

Lima, L., and Reed, M. (2000). "Reflexiones sobre la reubicación y el restablecimiento: una respuesta al desplazamiento forzado por la violencia en Colombia," in Reasentamiento en Colombia, ed. W. Partidgre (Bogotá: Banco Mundial, Alto Comisionado de Naciones Unidas), 289-315.

Madariaga, C. (2002). Trauma Psicosocial, Trastorno de Estres Postraumático y Tortura. Brazil: CINTRAS.

Manrique, K., Martínez, M., Turizo, and Amarís, M. (2008). Estudio Correlacional Entre el Bienestar Psicológico, Subjetivo y Social, y el Fatalismo, el Trauma y Las Cogniciones Irracionales Postraumáticas, en Personas Adultas, Desplazadas por la Violencia Sociopolitica, Radicadas en la Ciudad de Barranquilla. Barranquilla: Universidad del Norte.

Martín Baró, I. (1990). Psicología Social de la Guerra: Trauma y Terapia. San Salvador: UCA Editores.

Martín Baró, I., Punamäki, R. L., and Rozitchner, L. (1990). Psicología Social de la Guerra: Trauma y Terapia. San Salvador: UCA Editores.

McDonald, R. (1981). The dimensionality of tests and ítems. Br. J. Math. Stat. Psychol. 34, 100-117. doi: 10.1111/j.2044-8317.1981.tb00621.x

McDowell, I. (2010). Measures of self-perceived well-being. J. Psychosom. Res. 69, 69-79. doi: 10.1016/j.jpsychores.2009.07.002

Medina-Montañez, M. V., Layne, B., Galeano, M. P., and Lozada, C. (2007). Lo psicosocial desde una perspectiva holística. Rev. Tendenc. Retos 12, 177-189.

Mejía, A. (2019). Desterritorialización y Reterritorialización de la Población Desplazada Del Sur Del Tolima en Proceso de Retorno y Reubicación. Elementos Desde el Ordenamiento Territorial. Bogata: Universidad Nacional de Colombia.

Montero, I., and León, O. (2007). A guide for naming research studies in psychology. Int. J. Clin. Health Psychol. 7, 847-862.

Muñiz, J. (1998). Teoría Clásica de Los Tests. Madrid: Ediciones Pirámide.

Palacio, J., Abello, R., Madariaga, C., and Sabatier, C. (1999). Estrés postraumático y resistencia psicológica en jóvenes desplazados. Invest. Desarrollo 10, 16-29.

Palacio, J., Jimenez, S., and Abello, R. (2003). Identidad social y restablecimiento urbano de población exiliada internamente en Colombia: resultados de un estudio de caso. Invest. Desarrollo 11, 326-347.

Palacio, J., and Sabatier, C. (2002). El Contexto en Colombia. Impacto Psicológico de la Violencia Política en Colombia: Salud Mental y Redes Sociales en las Familias Desplazadas en el Caribe. Barranquilla: Ediciones Uninorte.

Peña Contreras, E. K., Lima Castro, S. E., Bueno Pacheco, G. A., Aguilar Sizer, M. E., Keyes, C. L. M., and Arias Medina, W. P. (2017). Fiabilidad y validez de la Escala del Contínuum de Salud Mental (MHC-SF) en el contexto ecuatoriano. Ciencias Psicol. 11, 223-232. doi: 10.22235/cp.v11i2.1499

Posada, D., Pabón, N., and Bahamón, M. (2013). Territorios en contexto de retorno: lecturas desde las representaciones sociales de los retornados de las veredas de Galilea y el Roble del municipio de Granada, Antioquia. Tendenc. Retos 18, 79-92.

Prieto, G., and Muñiz, J. (2000). Un modelo para evaluar la calidad de los test utilizados en España. Papeles Psicól. 77, 65-72.

Quintero, S. (2020). Modelo Analítico de las Relaciones Funcionales del Capital Social, Salud Mental, Afrontamiento Individual y Trauma Psicosocial en Jóvenes Víctimas del Conflicto Armado en Proceso de Retorno y Reubicación en Colombia. Doctoral Thesis. Barranquilla: Universidad Del Norte.

Ramírez, L. (2015). Revisión a la implementación de los programas de retorno. Una Mirada a partir de tres estudios de caso en el oriente antioqueño. El Ago. USB 15, 325-585. doi: 10.21500/16578031.1624

Rebolledo, O., and Rondón, L. (2010). Reflexiones y aproximaciones al trabajo psicosocial con víctimas individuales y colectivas en el marco del proceso de reparación. Rev. Estud. Soc. 36, 40-50. doi: 10.7440/res36.2010.04

Renner, A., Hoffmann, R., Nagl, M., Roehr, S., Jung, F., Grochtdreis, T., et al. (2020). Syrians refugees in Germany: perspective on mental health and coping strategies. J. Psychosom. Res. 129:109906. doi: 10.1016/j.jpsychores.2019.109906

Robles, J. (1997). Una aproximación al estudio de las variables mediadoras en la investigación psicológica. Argos 26-27, 157-171.

Ryff, C. D. (1989). Beyond Ponce de Leon and life satisfaction: new directions in quest of successful ageing. Int. J. Behav. Dev. 12, 35-55. doi: 10.1177/ 016502548901200102

Ryff, C. D., and Keyes, C. L. (1995). The structure of psychological well-being revisited. J. Pers. Soc. Psychol. 69, 719-727. doi: 10.1037/0022-3514.69.4.719

Sánchez, D., Castaño, G. A., Sierra, G. M., Moratto, N., Salas, C., Buitrago, C., et al. (2019). Salud mental de adolescentes y jóvenes víctimas de desplazamiento forzado en Colombia. Rev. CES Psicol. 12, 1-19. doi: 10.21615/cesp. 12.3 .1

Schneider, C. B., Pilhatsch, M., Rifati, M., Josh, W. H., Wodarz, F., Ebersbach, G., et al. (2010). Utility of the WHO-five well-being index as a screening tool for depression in Parkinson's disease. Mov. Disord. 25, 777-783. doi: 10.1002/mds. 22985

Seligman, M., and Csikzentmihalyi, M. (2001). "Positive psychology: an introduction": Reply. Am. Psychol. 56, 89-90. doi: 10.1037/0003-066X.56.1.89

Sharma, S., Durand, R., and Gur-Arie, O. (1986). Identification and analysis of moderator variables. J. Market. Res. 18, 291-300. doi: 10.1177/ 002224378101800303 
Siriwardhana, C., and Stewart, R. (2013). Forced migration and mental health: prolonged internal displacement, return migration and resilience. Int. Health 5, 19-23. doi: 10.1093/inthealth/ihs014

Sisask, M., Värnik, A., Kõlves, K., Konstabel, K., and Wasserman, D. (2008). Subjective psychological well-being (WHO-5) in assessment of the severity of suicide attempt. Nord. J. Psychiatry 62, 431-435. doi: 10.1080/ 08039480801959273

Sullivan, D. (2019). Obstáculos Comunes Para el Retorno: los Rohinyá y los Sursudaneses. Available online at: www.fmreview.org/es/retorno (accessed June 30, 2020).

Summerfield, D. (2001). The invention of post-traumatic stress disorder and the social usefulness of a psychiatric category. BMJ Br. Med. J. 322, 95-98. doi: 10.1136/bmj.322.7278.95

Thompson, N., and Walsh, M. (2010). The existential basis of trauma. J. Soc. Work Pract. 24, 377-389. doi: 10.1080/02650531003638163

Unidad de Atención y Reparación Integral a las Víctimas [UARIV] (2018). Reporte Registro Único de Victimas. Colombia: UARIV.

Unidad de Atención y Reparación Integral a las Víctimas [UARIV] (2020). Reporte Registro Único de Victimas. Colombia: UARIV.
Velásquez, P., and Céspedes, C. (2019). Procesos de retorno: mecanismos gubernamentales para asumir el desplazamiento. Trabajo Soc. 21, 141-166. doi: $10.15446 /$ ts.v2 $\ln 2.75088$

Villagrán, L. (2016). Trauma Psicosocial: Naturaleza, Dimensiones y Medición. Doctoral Thesis. Madrid: Universidad Autónoma de Madrid.

Wen, Z.-L., Hau, K.-T., and Chang, L. (2005). A comparison of moderator and mediator and their applications. Acta Psychol. Sin. 37, 268-274.

Conflict of Interest: The authors declare that the research was conducted in the absence of any commercial or financial relationships that could be construed as a potential conflict of interest.

Copyright (c) 2020 Quintero-González, Madariaga-Orozco, Millán-de Lange, Castellar-Jiménez and Palacio-Sañudo. This is an open-access article distributed under the terms of the Creative Commons Attribution License (CC BY). The use, distribution or reproduction in other forums is permitted, provided the original author(s) and the copyright owner(s) are credited and that the original publication in this journal is cited, in accordance with accepted academic practice. No use, distribution or reproduction is permitted which does not comply with these terms. 